\title{
PERFORMANS SAPI BALI YANG DIBERI RUMPUT LAPANGAN DENGAN TAMBAHAN DEDAK GANDUM (POLLARD) DAN TEPUNG DAUN KELOR (Moringa oleifera)
}

\author{
BUDIANA, I N*., I G. L. O. CAKRA, DAN I. B. G. PARTAMA \\ *Program Studi Magister Ilmu Peternakan \\ Fakultas Peternakan Universitas Udayana \\ e-mail: nyoman_budiana@yahoo.co.id
}

\begin{abstract}
ABSTRAK
Penelitian tentang performans sapi bali yang diberi rumput lapangan dengan tambahan dedak gandum (pollard) dan tepung daun kelor (Moringa oleifera) telah dilaksanakan. Penelitian menggunakan rancangan acak kelompok (RAK) dengan empat perlakuan dan empat ulangan. Sebanyak 16 ekor sapi bali jantan digunakan dalam penelitian ini. Masing-masing kelompok diberikan perlakuan pakan yang terdiri dari pakan tambahan $1 \mathrm{~kg}$ pollard dengan pakan dasar rumput lapangan (Po), pakan tambahan $1 \mathrm{~kg}$ pollard dan tepung daun kelor 5\% dengan pakan dasar rumput lapangan (P1), pakan tambahan $1 \mathrm{~kg}$ pollard dan tepung daun kelor 10\% dengan pakan dasar rumput lapangan ( $\mathrm{P} 2)$ serta pakan tambahan $1 \mathrm{~kg}$ pollard dan tepung daun kelor $15 \%$ dengan pakan dasar rumput lapangan ( $\mathrm{P}_{3}$ ). Variabel yang diamati adalah bobot badan, konsumsi pakan, dan konversi pakan, Hasil penelitian menunjukkan adanya perbedaan yang tidak nyata $(\mathrm{P}>0,05)$ pada keempat perlakuan pada semua variabel yang diamati. Sapi bali yang diberikan pakan tambahan pollard dan $15 \%$ tepung daun kelor pada pakan dasar rumput lapangan ( $\mathrm{P}_{3}$ ) menghasilkan bobot badan, konsumsi pakan, dan efisiensi penggunaan pakan yang tidak berbeda nyata dibandingkan dengan perlakuan yang lain.
\end{abstract}

Kata kunci: sapi bali, pakan tambahan, konversi pakan

\section{PERFORMANCE OF BALI CATTLE GIVEN FIELD GRASS WITH ADDITIONAL OF POLLARD AND MORINGA (MORINGA OLEIFERA) LEAF MEAL}

\begin{abstract}
An experiment was carried out to study the performance of bali cattle given field grass with additional of pollard and moringa (Moringa oleifera) leaf meal. The experiment was conducted. A randomized block design (RBD) with four treatments and four replicates was used in this experiment. Total of 16 bali cattles were used in this experiment. The treatments were $1 \mathrm{~kg}$ polard additional with field grass as based ration (Po or control), $1 \mathrm{~kg}$ polard additional and $5 \%$ moringa leaf meal with field grass as based ration (P1), $1 \mathrm{~kg}$ polard additional and $10 \%$ moringa leaf meal with field grass as based ration ( $\mathrm{P}_{2}$ ) and $1 \mathrm{~kg}$ polard additional and $15 \%$ moringa leaf meal with field grass as based ration ( $\mathrm{P}_{3}$ ). Variables observed were live weight, feed consumption, feed convertion ratio, nutrient consumption and nutrient intake. The results showed that no different effect $(\mathrm{P}>0.05)$ found in all treatments. Bali cattle given $1 \mathrm{~kg}$ polard additional and 15\% moringa leaf meal with field grass as based ration ( $\left.\mathrm{P}_{3}\right)$ resulted live weight, feed convertion ratio, nutrient consumption, and nutrient intake no significant different than other treatments.
\end{abstract}

Keywords: bali cattle, additional feed, performance, feed consumption, feed conversion

\section{PENDAHULUAN}

Pengembangan sapi bali dihadapkan pada masalah ketersediaan bahan pakan baik dari segi kualitas maupun kuantitasnya. Pakan hijauan merupakan pakan yang dibutuhkan ternak ruminansia dalam jumlah besar. Pakan hijauan cukup tersedia pada musim hujan namun ketersediaannya terus menurun memasuki musim kemarau. Walaupun jumlah pakan cukup tersedia pada musim hujan sering kali kualitas nutrisinya belum dapat memenuhi kebutuhan ternak terutama pakan yang berasal dari rumput alam yang memang mempunyai kandungan nutrisi yang rendah dan kualitas nutrisinya menurun sangat cepat seiring 
dengan datangnya musim kemarau. Sehingga sering terjadi ternak mengalami kekurangan nutrisi hampir sepanjang tahun.

Pemberian pakan tambahan merupakan salah satu cara yang dilakukan peternak untuk mengatasi hal tersebut. Berbagai jenis pakan tambahan diberikan oleh peternak salah satunya yang banyak diberikan adalah dedak gandum (pollard). Pollard merupakan limbah industri pertanian, hasil sampingan dari pengolahan gandum. Memiliki kandungan nutrisi yang cukup baik sebagai sumber energi dengan kandungan karbohidrat $64,75 \%$, protein $11,99 \%$, lemak 1,48\%, abu 0,64\% dan serat kasar 3,75\% (Martawijaya, 2004). Namun pemberian pakan tambahan pollard sering tidak diikuti dengan penambahan pakan sumber protein seperti bungkil kelapa, bungkil kedelai atau hijauan yang berasal dari jenis leguminosa.

Tanaman kelor (Moringa oleifera) berdasarkan beberapa hasil penelitian mempunyai potensi yang besar sebagai sumber protein ternak, mengandung berbagai jenis zat nutrisi yang berfungsi sebagai obat yang dapat menjaga kesehatan ternak. Tanaman kelor mempunyai kemampuan memproduksi biomassa yang tinggi mencapai 4,2 - 8,3 ton bahan kering/ha pada interval pemotongan 40 hari dan kandungan nutrisi terutama protein kasar daun berkisar 19,3 - 26,4 \% (Makkar dan Becker, 1996). Produksi yang berlebihan pada musim hujan, daun kelor dapat dikeringkan kemudian disimpan dalam bentuk tepung. Daun kelor dapat diberikan pada ternak ruminansia baik dalam bentuk segar maupun olahan seperti tepung daun kelor. Berdasarkan hal ini maka peneliti tertarik untuk melakukan penelitian terhadap pemberian pakan tambahan pollard sebagai sumber energi yang dicampur tepung daun kelor sebagai sumber protein pada sapi bali dengan pakan dasar rumput lapangan.

Penelitian bertujuan untuk mengetahui performans sapi bali yang diberikan pakan tambahan pollard dan tepung daun kelor dengan pakan dasar rumput lapangan dan untuk mengetahui level optimal pemberian tepung daun kelor dalam ransum.

\section{MATERI DAN METODE}

\section{Bahan Penelitian}

Penelitian ini menggunakan sapi bali jantan penggemukan milik peternak di Desa Gadung Sari Kecamatan Selemadeg Timur Kabupaten Tabanan sebanyak 16 ekor dengan rata-rata bobot badan awal sapi pada masing masing perlakuan berkisar antara 218 sampai $220 \mathrm{~kg}$.

Pakan yang diberikan pada penelitian ini adalah rumput lapangan sebagai pakan dasar dengan memberikan pakan tambahan berupa dedak gandum (pollard) dan tepung daun kelor pada beberapa level. Kandungan nutrisi bahan pakan berdasarkan hasil analisis proximat Laboratorium Nutrisi dan Makanan Ternak Fakultas Peternakan Universitas Udayana disajikan pada Tabel 1.

\begin{tabular}{ccccccc}
\multicolumn{7}{l}{ Tabel 1. Kandungan nutrisi bahan pakan } \\
\hline Sampel & BK(\%) & ABU (\%) & SK (\%) & PK(\%) & LK (\%) & BETN (\%) \\
\hline A & 86,15 & 3,73 & 5,95 & 16,28 & 5,72 & 54,47 \\
B & 88,71 & 4,07 & 7,11 & 17,08 & 5,67 & 54,79 \\
C & 86,68 & 4,12 & 7,86 & 17,55 & 5,49 & 51,65 \\
D & 89,55 & 4,39 & 8,76 & 17,36 & 5,84 & 53,21 \\
E & 21,80 & - & 34,20 & 6,70 & 1,80 & - \\
\hline
\end{tabular}

Keterangan:

$A=100 \%$ pollard, $B=95 \%$ pollard dan $5 \%$ tepung daun kelor , $C=90 \%$ pollard dan $10 \%$ tepung daun kelor, $\mathrm{D}=85 \%$ pollard dan $15 \%$ tepung daun kelor, $\mathrm{E}=$ Rumput lapangan

\section{Lokasi dan Waktu Penelitian}

Penelitian dilaksanakan di Desa Gadung Sari, Kecamatan Selemadeg Timur Kabupaten Tabanan Provinsi Bali selama 4 bulan dimulai pada bulan Oktober 2015 sampai dengan Februari 2016

\section{Rancangan Penelitian}

Rancangan penelitian menggunakan rancangan acak kelompok (RAK) dimana pengelompokkan dilakukan berdasarkan bobot badan sapi dengan rata-rata bobot badan awal sapi sebesar 218,38 kg. Perlakuan yaitu pemberian pakan tambahan $1 \mathrm{~kg}$ pollard dengan pakan dasar rumput lapangan (Po), pemberian pakan tambahan $1 \mathrm{~kg}$ pollard dan 5\% tepung daun kelor dengan pakan dasar rumput lapangan (P1), pemberian pakan tambahan $1 \mathrm{~kg}$ pollard dan $10 \%$ tepung daun kelor dengan pakan dasar rumput lapangan (P2) dan pemberian pakan tambahan $1 \mathrm{~kg}$ pollard dan $15 \%$ tepung daun kelor dengan pakan dasar rumput lapangan ( $\mathrm{P}_{3}$ ). Masing-masing perlakuan diulang sebanyak 4 kali sehingga terdapat 16 ekor sapi bali yang digunakan dalam penelitian ini.

\section{Variabel Penelitian}

Variabel yang diamati dalam penelitian ini adalah bobot badan, konsumsi pakan, dan konversi pakan atau feed conversion ratio (FCR).

\section{Analisis Data}

Data yang diperoleh dianalisis dengan sidik ragam, bila hasil analisis sidik ragam menunjukkan perbedaan yang nyata $(\mathrm{P}<0,05)$ diantara perlakuan maka dilanjutkan dengan analisis uji Jarak Berganda Duncan pada taraf 5\% (Steel dan Torrie, 1980). 


\section{HASIL DAN PEMBAHASAN}

Rataan bobot badan akhir sapi bali dengan perlakuan Po, P1, P2 dan $\mathrm{P}_{3}$ berturut-turut adalah 273,38 kg; $282,13 \mathrm{~kg} ; 284,88 \mathrm{~kg}$, dan 286,50 kg (Tabel 2), secara statistik berbeda tidak nyata $(\mathrm{P}>0,05)$ antar perlakuan. Hal ini disebabkan karena pemberian daun kelor sampai $15 \%$ pada pakan tambahan pollard belum berpengaruh terhadap ketersediaan nutrisi bagi mikroba rumen.

Tabel 2. Performans sapi bali yang diberikan pakan tambahan pollard dan tepung daun kelor pada beberapa level

\begin{tabular}{|c|c|c|c|c|c|}
\hline \multirow{2}{*}{ Parameter } & \multicolumn{4}{|c|}{ Perlakuan ${ }^{2)}$} & \multirow{2}{*}{- SEM $^{3)}$} \\
\hline & PO & P1 & $\mathrm{P} 2$ & P3 & \\
\hline Bobot badan awal (kg) & $218,63^{a 1)}$ & $218,00^{a}$ & $218,25^{a}$ & $218,63^{a}$ & 30,73 \\
\hline Bobot badan akhir (kg) & $273,38^{a}$ & $282,13^{a}$ & $284,88^{a}$ & $286,50^{a}$ & 29,92 \\
\hline $\begin{array}{l}\text { Pertambahan bobot } \\
\text { badan (kg/ekor/hari) }\end{array}$ & $0,46^{\mathrm{a}}$ & $0,53^{a}$ & $0,56^{a}$ & $0,57^{a}$ & 0,04 \\
\hline $\begin{array}{l}\text { Konsumsi pakan (kg BK/ } \\
\text { ekor/hari) }\end{array}$ & $5,44^{a}$ & $6,31^{a}$ & $6,35^{a}$ & $6,65^{a}$ & 0,39 \\
\hline Konversi pakan & $11,92^{a}$ & $11,83^{a}$ & $11,43^{a}$ & $11,76^{a}$ & 0,82 \\
\hline
\end{tabular}

Keterangan:

1) Huruf superskrip yang sama pada baris yang sama menunjukkan perbedaan yang tidak nyata $(P>0,05)$

2) $\mathrm{PO}=$ pakan tambahan $1 \mathrm{~kg}$ pollard dengan pakan dasar rumput lapangan; $\mathrm{P} 1$ = pakan tambahan pollard dan tepung daun kelor $5 \%$ dengan pakan dasar rumput lapangan; P2 = pakan tambahan pollard dan tepung daun kelor 10\% dengan pakan dasar rumput lapangan; P3 = pakan tambahan pollard dan tepung daun kelor $15 \%$ dengan pakan dasar rumput lapangan

3) Standard Error of the Treatment Means

Pertambahan bobot badan harian terendah terdapat pada sapi bali yang diberikan perlakuan pakan Po dibandingkan dengan $\mathrm{P}_{1}, \mathrm{P}_{2}$ dan $\mathrm{P}_{3}$. Sapi bali yang diberikan pakan Po, pertambahan bobot badannya masing-masing 13,21\%; $17,86 \%$ dan 19,30\% lebih rendah dibandingkan dengan sapi bali yang diberikan pakan dengan perlakuan $\mathrm{P}_{1}, \mathrm{P}_{2}$ dan $\mathrm{P}_{3}$ namun secara statistik berbeda tidak nyata $(\mathrm{P}>0,05)$. Rataan bobot badan akhir dan pertambahan bobot badan walaupun secara statistik berbeda tidak nyata namun cenderung terjadi peningkatan. Hal ini disebabkan karena adanya peningkatan konsumsi pakan sapi bali pada perlakuan $\mathrm{P}_{1}, \mathrm{P} 2$, dan $\mathrm{P}_{3}$ dengan angka konsumsi pakan masingmasing $6,31 \mathrm{~kg} /$ ekor/hari $6,36 \mathrm{~kg} /$ ekor/hari dan 6,65 $\mathrm{kg} /$ ekor/hari (Tabel 2). Hal ini didukung pendapat Nuriyasa (2012) yang menyatakan bahwa konsumsi pakan paling tinggi menghasilkan bobot badan paling tinggi. Bobot badan akhir dan pertambahan bobot badan sapi bali dipengaruhi oleh jumlah pakan yang dikonsumsi dan nutrien yang diserap dalam tubuhnya. Tillman etal. (1991) menyatakan bahwa makanan adalah faktor yang mendominasi kecepatan pertambahan bobot badan, sebab komposisi makanan lebih banyak mempengaruhi pembentukan jaringan tubuh secara alamiah. Selanjutnya dinyatakan bahwa konsumsi pakan yang tinggi mengindikasikan bahwa nutrien yang diserap tubuh lebih banyak dengan hasil akhir adalah bobot badan dan pertambahan bobot badan harian yang tinggi. Hal ini didukung oleh pernyataan Nurwahidah et al. (2016) bahwa apabila nilai nutrisi pakan mencukupi untuk kebutuhan hidup ternak, akan memberikan pengaruh positif terhadap pertumbuhannya.

Konsumsi pakan sapi bali yang diberikan pakan tambahan pollard dengan pakan dasar rumput lapangan (Po), pakan tambahan pollard dan tepung daun kelor 5\% dengan pakan dasar rumput lapangan (P1), pakan tambahan pollard dan tepung daun kelor 10\% dengan pakan dasar rumput lapangan ( $\mathrm{P} 2)$ serta pakan tambahan pollard dan tepung daun kelor $15 \%$ dengan pakan dasar rumput lapangan $\left(\mathrm{P}_{3}\right)$ masingmasing adalah $5,44 \mathrm{~kg} ; 6,31 \mathrm{~kg} ; 6,35 \mathrm{~kg}$ dan $6,65 \mathrm{~kg}$ (Tabel 2). Konsumsi pakan sapi bali pada perlakuan Po berturut-turut adalah 13,79\%; 14,33\% dan 18,20\% lebih rendah dibandingkan dengan perlakuan $\mathrm{P}_{1}, \mathrm{P}_{2}$ dan $\mathrm{P}_{3}$. Secara kualitatif, penambahan tepung daun kelor dalam pakan sapi bali sampai dengan taraf $15 \%$ berpengaruh tidak nyata $(\mathrm{P}>0,05)$ terhadap konsumsi pakan. Hal ini disebabkan karena pemberian tepung daun kelor sampai dengan taraf $15 \%$ pada pakan tambahan pollar belum memberikan pengaruh terhadap faktorfaktor yang mempengaruhi konsumsi pakan seperti palatabilitas dan yang lainnya. Namun secara kuantitatif penambahan tepung daun kelor dalam pakan sampai dengan $15 \%$ cenderung dapat meningkatkan konsumsi pakan. Hal ini mungkin disebabkan oleh adanya peningkatan keseimbangan nutrien dalam pakan. Konsumsi pakan yang maksimum sangat tergantung pada keseimbangan nutrien dalam pencernaan karena kebutuhan nutrisi merupakan perangsang utama untuk disampaikan ke hipotalamus sebagai pusat lapar. Imbangan nutrien berhubungan dengan fermentasi rumen, dimana karbohidrat dan faktor lainnya akan mempengaruhi fermentasi rumen yang pada gilirannya akan mempengaruhi konsumsi pakan.

Konversi pakan yang didapatkan pada perlakuan Po, P1, P2 dan P3 secara berurut-turut adalah: 11,92; 11,83; 11,43 dan 11,76. Konversi pakan sapi bali yang diberikan perlakuan $\mathrm{P}_{1}, \mathrm{P}_{2}$ dan $\mathrm{P}_{3}$ berturut-turut adalah $0,76 \%$ 4,29\% dan 3,36\% lebih rendah dibandingkan dengan Po. Penambahan pollard dan tepung daun kelor sampai dengan $15 \%$ dengan pakan dasar rumput lapangan pada sapi bali berpengaruh tidak nyata $(\mathrm{P}>0,05)$ terhadap konversi pakan, namun secara kuantitatif cenderung menurun seiring dengan meningkatnya persentase penambahan tepung daun kelor. Hal ini disebabkan karena penambahan daun kelor kemungkinan dapat meningkatkan populasi mikroba didalam rumen yang akan memberikan dampak pada proses fermentasi. Didalam rumen karbohidrat komplek yang meliputi selulosa, hemiselulosa dan lignin dengan adanya aktivitas fermentatif oleh mikroba akan dipecah 
menjadi asam atsiri khususnya asam asetat, propionat dan butirat (Ranjhan dan Pathak, 1979). Semakin rendah angka konversi pakan berarti kualitas pakan semakin baik. Tillman et al. (1991) menyatakan bahwa tinggi rendahnya kualitas pakan sangat ditentukan oleh kandungan protein dalam pakan. Menurut Putri (2011) kelebihan daun kelor sebagai sumber nutrisi adalah daun kelor mengandung nutrisi paling lengkap dibandingkan tumbuhan jenis apapun. Selain vitamin dan mineral, daun kelor mengandung asam amino esensial yaitu asam amino yang tidak diproduksi sendiri oleh tubuh sehingga harus diberikan tambahan dalam bentuk jadi. Apabila protein lebih banyak dimanfaatkan untuk sintesa jaringan tubuh akan mengindikasikan bahwa pemanfaatan protein lebih efisien. Konversi pakan yang semakin menurun pada perlakuan P1, P2, dan P3 menunjukkan bahwa sapi bali lebih efisien memanfaatkan pakan dasar rumput lapangan yang ditambahkan pollard dan tepung daun kelor sampai dengan $15 \%$. Nilai konversi hasil penelitian ini sesuai dengan pendapat Siregar (2008) yang menyatakan bahwa konversi pakan untuk sapi yang baik adalah 8,56 sampai dengan 13,29.

\section{SIMPULAN}

Berdasarkan hasil dan pembahasan dapat disimpulkan bahwa pemberian pakan tambahan $1 \mathrm{~kg}$ pollard dan tepung daun kelor sampai level 15\% dengan pakan dasar rumput lapangan belum dapat meningkatkan performans (bobot badan, pertambahan bobot badan, konsumsi pakan dan konversi pakan) pada sapi bali.

\section{DAFTAR PUSTAKA}

Makkar, H. P. S. and K. Becker. 1996. Nutritional value and antinutritional component of whole and ethanol extracted Moringa oleifera leaves. Anim. Feed Sci Technol. 63:211-228.

Martawijaya, E. 2004. Panduan Beternak Itik Petelur Secara Intensif. Agromedia Pustaka. Jakarta.

Nuriyasa, M. 2012. Respon Biologi serta Pendugaan Kebutuhan Energi dan Protein Ternak Kelinci Kondisi Lingkungan Berbeda di Daerah Dataran Rendah Tropis. Disertasi. Program Pasca Sarjana. Universitas Udayana Denpasar.

Nurwahidah, J., A. L. Toeng, dan M. N. Hidayat. 2016. Pengaruh pemberian pakan konsentrat dan urea molases bok (UMB) terhadap pertambahan berat badan sapi potong. JIIp. Volume 2 Nomor 2. Hal. 111-121.

Putri, O. D. 2011. Sejuta Khasiat Daun Kelor. Berlian Media, Jakarta.

Ranjhan, S. K. and N. N. Pathak, 1979. Management and Feeding of Buffalo, Vikas Publ House put, New Delhi.

Siregar, S. B. 2008. Penggemukan Sapi. Penebar Swadaya. Jakarta.

Steel, R. G. D. dan J. H. Torrie. 1980. Prinsip dan Prosedur Statistika Suatu Pendekatan Biometrik. Edisi Kedua. Diterjemahkan oleh Sumantri Gramedia. Jakarta.

Tillman, Hartadi, Reksohadiprodjo, Prawirokusumo dan Lebdosoekojo. 1991. Ilmu Makanan Ternak Dasar. Cetakan ke-6. Gadjah Mada University Press. Yogyakarta. 